\title{
Local Geo-politics of Urban Food Resilience to Achieve Sustainable City Development in Malang, Indonesia
}

\author{
Muhammad Kamil $^{1 *}$, Ach. Apriyanto Romadhan ${ }^{1}$

\begin{abstract}
${ }^{1}$ Department of Government Studies University of Muhammadiyah Malang, Malang, Indonesia
\end{abstract} \\ ${ }^{*}$ Corresponding author. Email: kamil@umm.ac.id
}

\begin{abstract}
Conversion of agricultural land functions into settlements in the city of Malang is a major factor in achieving urban food security. The area of agricultural land in Malang City is 1,104 ha, mostly dominated by rice farming, which is 821 ha, the rest is agricultural land that is used by sugar cane, horticulture or vegetables. In its development, every year it experiences a shrinkage of between $2-5 \%$. The land conversion has occurred because of the increasing need for housing. The Government of Malang City has committed to achieve the Sustainable Development Goals (SDGs) target, namely by carrying out safe food management. This research focuses on the local geopolitics of Malang City Government in food independence to achieve Sustainable City Development. This research uses a qualitative descriptive approach with a case study approach. The data is obtained from primary data obtained from observations, interviews, and documentation, while secondary data is obtained from literature review of several local government report documents, research journals related to food security and independence policies in Malang. Malang City succeeded in managing food safety by optimizing the potential of Natural Resources both land for agriculture, land, human resources and other food resources for the utilization of food security and nutrition. In addition, access to adequate food and nutrition (1) Connecting government power and local potential through the establishment of food security villages, (2) Development of cooperation through the Urban Farming program and (3) Relationship of local policies and politics in the Sustainable Food Home Area programs.
\end{abstract}

Keywords: local geo-politics, natural resources, food resilience, sustainable city development

\section{INTRODUCTION}

Geopolitics and local politics are the impact of decentralization [1]. Conversion of agricultural land functions into settlements in the city of Malang is a major factor in achieving urban food security. The area of agricultural land in Malang City is 1,104 ha, mostly dominated by rice farming, which is 821 ha, the rest is agricultural land that is used by sugar cane, horticulture or vegetables. In its development, every year it experiences a shrinkage of between $2-5 \%$. This research focuses on the local geo-politics of the Malang city government in food independence to achieve sustainable city development.

Local geopolitics is neither geographically deterministic, nor is it wedded to the absurd notion that particular features of physical geography have an inherent, unchanging significance. Geopolitics does insist, though, that spatial factors to be accorded their due [2]. Political ecologies that the government, thought its institution and policies, and mobilize resource and people to take on the challenge [3]. Food security is an effort to meet food needs for each region. The consequence of decentralization for urban governments is to be able to repair and prevent boundaries and boundaries and distortions in the global market [4]. Contemporary willingness to move beyond the "territorial trap" of modern geopolitics, by emphasizing cities' agency in global affairs and by calling for the production of globally comparable urban data, induces a process of reframing and rescaling existing understandings of the global [5]. Malang city is experiencing a land crisis. The shrinking of agricultural land in the city of Malang makes food supply automatically shrinking. Malang City as an education, industry and tourism city has led to the development of the city to the periphery because of the accumulation of various activities of basic functions and other activities that grew due to the encouragement of these basic functions. The residential or housing facilities which are the main facilities in urban development to get priority in handling them. To overcome this, the poor city government needs to find alternatives so that it can continue to have food security and sovereignty by food for work programs and income and transfer program [6]. Such conditions are inseparable from the politics of government policy as city managers and power in urban communities.

The issue of food insecurity is more a political problem than an agricultural problem [7]. The main source of food insecurity is not food scarcity, but policy [8]. Recurring food crises, let alone accompanied by economic recession, make poor cities vulnerable in uncertainty [9]. The global political architecture will be dominated by food, so that the battle in meeting and controlling food availability will determine the movement of local geopolitical movements in Malang. 


\section{RESEARCH METHODS}

In order to obtain data needs in mapping local geopolitics in achieving food resilience, food security and independence in Malang, the study used a qualitative approach by Creswell [10] with primary data sources obtained directly from informants, while secondary data sources were obtained from supporting documents of the government of Malang, journals and other documents. The data collection techniques using the method of field observation related to land use, agriculture land condition and urban spatial planning. The second technique is interviews with the government to get data information about political power strategy and how-to connecting government power with local resources, and third techniques with the data documentation. While data on local geopolitics is analysing based on Creswell data analysis techniques, namely interpreting interview and observation data, coding data as a processing information about local geo politics in Malang and making conclusions.

\section{RESULTS AND DISCUSSION}

The government power of urban food resilience based on geographical and political conditions is manifested in several ways: (1) Connecting government power and local potential through the establishment of food security villages, (2) Development of cooperation through the Urban Farming program and (3) Relationship of local policies and politics in the Sustainable Food Home Area program.

\subsection{Government power and potential resources connecting}

The land conversion has occurred because of increasing need for housing as a strategy [11]. The regional government of Malang has committed to achieve the Sustainable Development Goals target with connecting among government power with potential resources, by carrying out safe food management. Malang City succeeded in managing food safety by optimizing the potential of natural resources both land for agriculture, human resources and other resources for the utilization of food security through comparing government policy with local politics. The access to adequate food and nutrition by empowering agricultural land, house yards and abandoned land, strengthening food affordability so that food access smoothly reaches the family, accelerates food diversification in the community based on local food base other than rice.

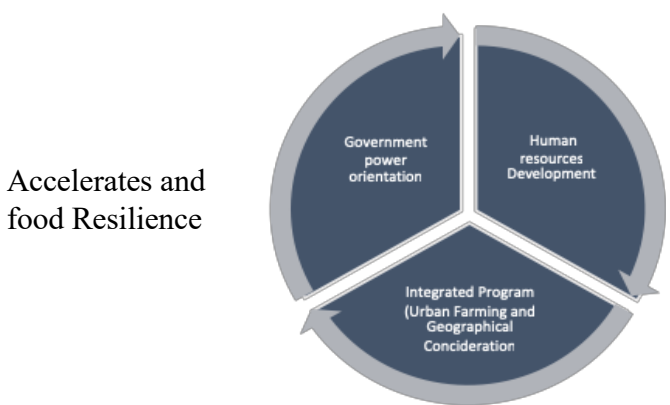

Figure 1 Government power and potential resources connecting

In achieving the aspirations of the city government in each period of development, the government through the agriculture and food security services continues to make efforts to increase the ability of domestic food production or self-sufficiency, stabilize food prices, and reduce dependence on imports in order to avoid the food crisis. the main focus from Malang government. Food security is a condition for the fulfilment of food for the state up to the individual, which is reflected in the availability of sufficient food, both in quantity and quality, safe, diverse, nutritious, equitable, and affordable, and does not conflict with religion, beliefs and culture of the community, to be able to live healthy, active and productive sustainably. Through an urban farming program that connects government power with local potential, the community can take advantage of the limited land by farming. Conventional agriculture to urban agriculture, it is hoped that it can encourage economic growth in Malang City. In this way it can also help the government to control inflation in Malang.

In achieving the aspirations of the city government in each period of development, the government through the agriculture and food security services continues to make efforts to increase the ability of domestic food production, stabilize food prices, and reduce dependence on imports in order to avoid the food crisis. The main focus of government. Through the establishment of food security villages in Purwantoro, Lowokwaru sub-district, with a model of fostering communities that raise livestock, building aquarium villages and utilizing yards to grow vegetables. The implementation of regional autonomy has brought great changes to the poor city in the pattern and implementation of development, including development in the food sector. From the policy aspect to the political aspect based on geographical considerations.

\subsection{Cooperation Development Strategic and Urban Farming Model}

Efforts to achieve sustainable agriculture in Malang, Cooperation development policies aimed at reducing the negative impacts of regional development to the outskirts of Malang City are associated with high settlement needs and agricultural sustainability as an effort to reduce the impact of environmental degradation and contribution to food needs. The improvement and updating of agricultural technology, that farmers are expected to be able to survive with maximum profit. The urban agriculture program 
becomes a means of controlling inflation in the city of Malang. This urban farming program not only involves government organizing stakeholders, but also collaborate with the Family welfare Empowerment group (PKK) mobilizing team to support food security for the realization of zero stunting.

Land use change is a mechanism that brings demand and supply for land and produces institutional new materials with different production system characteristics. Transfer of land functions can also be interpreted as part of the transformation journey of the national economic structure, high population and economic growth at the city level causes land conversion with varying levels of transition between periods and regions. The growth machine that is concentrated on the development in Malang City. the development of a city is not formed on the interests of government alone but rather there are forces outside the government that are business oriented and economic profit. The power of business which then grows and dominates the use of space or in other words the most influential on the growth of Malang City.

Strengthening the capacity of the Watershed Processing Office as well as improving sewage treatment socialization related regulations and oversight of the companies in the industrial area [12]. Sustainable development is development that aims to improve the quality of life of people throughout the world, both from present and future generations, without exploiting of natural resources that exceed the capacity and carrying capacity of the earth. These goals can be achieved through four elements of sustainable development goals: (1) Growth and economic justice; (2) social development; (3) Conservation of natural resources for environmental protection; (4) Good governance. These four elements support one another, creating related and sustainable development goals.

In strengthening the quality of urban farming, the concept of "Beautiful and Comfortable Asri" is implemented in every village. This quality strengthening is realized by utilizing the land in the environment for farming. In order to realize the quality and output targets program, the government integrates urban farming with sustainable food houses. This integrated management program is in accordance with the mandate of law number 23 of 2014 concerning local governments that in order to achieve sustainable city development, the government needs to innovate as a significant breakthrough effort.

Urban farming innovation as a form of system development in realizing food security in Malang has been implemented by 57 villages. The optimism and commitment of the city government negates that the development of a city needs to be realized with the presence of the state in all matters of both government and society. Marginal sector marginalization or minimal community Education and knowledge become one of the objects of urban management.

\subsection{Relationship of local policies and politics}

The government agenda to realize food sovereignty through strategic food self-sufficiency in rice, corn, soybeans, sugar, and meat in the next five years should be valued and fully supported. It is realized that realizing food self-sufficiency is not easy because of the complex interaction of factors that affect food demand such as a growing population and an increase in people's income that affects consumption patterns with factors that affect food supply such as land availability, technology adoption, and climate diversity. Spatial planning will not be separated from political processes that are so dynamic. This is because space becomes one of the instruments in realizing various political interests by actors related to political studies in urban areas. Spatial planning itself has a very important function, namely, the formulation of the main policy on spatial use in urban areas, the realization of cohesiveness, interconnectedness and balance of development, including spatial planning for urban resilience in Malang city to achieving sustainable city development.

The explained that the target to be achieved with the twelfth SDG's objectives to achieve sustainable management and efficiency of natural resources. The management of consumption and production patterns. More specifically is about patterns of consumption and food production. SDG's goals number two and twelve can be interrelated and supportive. It can be seen with a target of goal number two that seeks to promote sustainable agriculture. These objectives ultimately impact on the sustainability of food production results. It also includes the achievement of targets on sustainable natural resource management and efficiency in SDG's goal number twelve. This will have an impact on the sustainability of consumption patterns and food production so that it can realize the food security of a region.

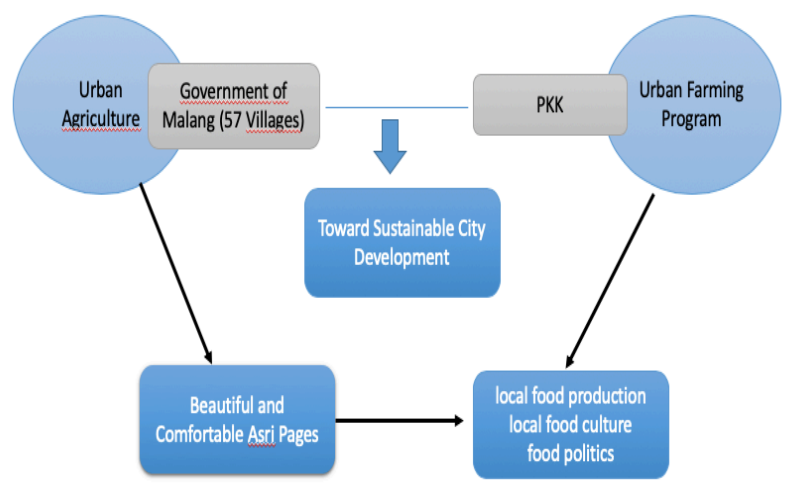

Figure 2 Malang Government strategic toward sustainable city development

The first pillar, the fulfilment of food production, means that although the strategic environment continues to experience changes, efforts to tackle food problems must still be overcome from domestic production and not rely on imports. Food imports are only carried out if domestic food production is inadequate and or the food is not produced domestically, as mandated in Law No. 18 of 2012 concerning Food. The second pillar, local food culture provides direction that the development of national food production must be based on paying attention to and strengthening local food culture. The importance and strategic significance of local food development also 
especially for small island areas and outermost island areas that are relatively at risk of greater food insecurity due to accessibility and disaster constraints. The third pillar of food politics requires that the development of food security must be part of the politics of national development. The problems and challenges faced in strengthening independent and sovereign food security are complex, the choice of supporting policies and the institutional environment must inevitably be implemented through a strong commitment to food politics. Strengthen the political support and commitment is needed as a driving force to enable the emergence of healthy food politics. The existence of Law No. 18 of 2012 is a support from government or executive and legislative political commitment in realizing food security. Furthermore, the Act must be implemented by spelling out in the form of regulations, policies, programs and budgets.

The policy of fulfilling the staple food of the community which so far has been based on rice has resulted in the abandonment of the development and eating patterns that were previously based on local food and turned to rice. Community eating patterns increasingly like things that are imported, instant, and practical. Behind the growing instant food culture, there is a tendency to reverse the tendency of food patterns to like local food patterns again, especially in the upper middle class because of health reasons and longing for ancestral food culture to be the cause. The turning point of food consumption patterns with local culture must be the basis for future food pattern policies.

\section{CONCLUSION}

In achieving sustainable city development, Malang city government has committed to achieving urban food security with the local geopolitics. Through policies based on local potential and local politics, the city government of Malang is able to meet urban food needs by implementing several strategies in achieving food security and sustainable city development. The achievement through with: (1) connecting among government power with potential resources, (2) integrating government policy to the local politics, and (3) focusing on regional development and cooperation to realize thru sustainable city development.

\section{ACKNOWLEDGMENT}

I would like to thank you to Social and Political Science Faculty, University of Muhammadiyah Malang that have fully supporting this research thought a block grant scheme in 2019 .

Furthermore, I would like to thank you to colleagues who have support and provided suggestions until this research completed.

\section{REFERENCES}

[1] T. L. Chou and T. C. Li, "Sustainability and river management in Taipei City, Taiwan," J. Urban Manag., vol. 1, no. 1, pp. 77-94, 2012.

[2] S. Scholvin, "Geopolitics: an Overview of Concepts and Empirical," no. April, 2016.

[3] E. J. Sessions, N. Workshop, S. Change, O. Amidst, and G. Transformation, "Beyond the environmental state ? Exploring the political prospects of a sustainability transformation," pp. 1-8, 2017.

[4] W. Chen, O. Zueva, A. Gorovoy, and S. Absalyamova, "Concept of ' Good Urban Governance ' and Its Application in Sustainable Urban Planning Concept of ' Good Urban Governance ' and Its Application in Sustainable Urban Planning," 2017.

[5] U. Geopolitics, "Interventions in Urban Geopolitics," no. April, pp. 1-40, 2017.

[6] C. F. Insecurity and T. F. Insecurity, "An Introduction to the Basic Concepts of Food Security Food Security Information for Action," pp. 1-3, 1996.

[7] Y. Perlu, D. Oleh, and P. Daerah, "Pembangunan berkelanjutan."

[8] C. Studies, "WHAT MAKES URBAN FOOD POLICY HAPPEN? Insights from five case studies," pp. 1-112.

[9] "UCLG Policy Paper Development Cooperation and Local Government."

[10] J. W. Creswell, "Research Design : Qualitative, Quantitative, and Mixed Methods Approaches," vol. 35, no. 2, pp. 2-4, 2009.

[11] R. Nallathiga, "Sustainability of Urban Fringe Development and Management : A Case Study of Fringe Area of NCT - Delhi," no. January, 2015.

[12] D. N. Kusumaningrum and P. P. Haffsari, "Good Governance for Sustainable Development: Municipal Waste Management," J. Int. Local Stud., vol. 1, no. 1, pp. 23-30, 2017. 